\title{
Biplot Analiz Yöntemi ile Bazı Makarnalık Buğday Hatlarının Verim ve Kalite Özelliklerinin Değerlendirilmesi
}

\author{
*Sertaç TEKDAL ${ }^{1}$, Enver KENDAL², Hüsnü AKTAȘ², Mehmet KARAMAN", \\ Hasan DOĞAN ${ }^{1}$, Sinan BAYRAM ${ }^{1}$, Mehmet DÜZGÜN¹ ${ }^{1}$, Ahmet EFE ${ }^{1}$ \\ ${ }^{1}$ GAP Uluslararası Tarımsal Araștırma ve Eğitim Merkezi Müdürlüğü, Diyarbakır \\ ${ }^{2}$ Artuklu Üniversitesi Kızıltepe Meslek Yüksekokulu, Mardin \\ *Sorumlu yazar e-posta (Corresponding author e-mail): sertac79@hotmail.com
}

\section{Öz}

Bu çalıșma, yağıșa dayalı olarak 2012-2013 ve 2013-2014 yetiștirme sezonlarında Diyarbakır'da yürütülmüș olup, verim ve kalite özellikleri üstün makarnalık buğday hatlarının belirlenmesi amaçlanmıștır. Araștırmada beș kontrol çeșit ve 20 hat materyal olarak kullanılmıștır. Deneme, tesadüf blokları deneme desenine göre dört tekerrürlü olarak kurulmuș ve tane verimi, hektolitre ağırlığı, bin tane ağırlığı, protein içeriği, irmik rengi ve SDS değeri incelenmiștir. Bileșik analiz sonucunda, genotip, yıl ve genotip x yıl interaksiyonlarında tüm özellikler yönünden önemli farklılıklar belirlenmiștir. Olușturulan Biplot grafiğinde, hatların çoğu protein oranı, irmik rengi ve SDS değeri gibi kalite özellikleri yönünde yer alarak üstünlük göstermișlerdir. İki yıllık ortalamalara göre, gerek verim ve gerekse kalite yönünden üstünlük gösteren bazı hatlar, ilerde tescil așamasında değerlendirilmek üzere bölge verim denemelerine alınmıștır.

Anahtar Kelimeler: Biplot, durum buğday, kalite, verim

\section{Evaluation of Yield and Quality Traits of Some Durum Wheat Lines with Biplot Analysis Method}

\section{Abstract}

This study was carried out to identify the superior properties of durum wheat lines in 2012-2013 and 2013-2014 growing season in Diyarbakir ecological conditions. Five standard varieties and 20 lines were used as research material. The experiment was established as a randomized complete block design technique with four replications and grain yield, thousand grain weight, hectoliter weight, protein content, grain color and SDS value were evaluated. According to the research results significant differences were recorded between genotypes, years and genotype $\mathrm{x}$ year interaction regarding all parameters. In the Biplot graphics formed with obtained values, many lines showed superiority regarding their protein ratio, semolina color and SDS values which represent the quality parameters. According to the two-year averages, promising genotypes having high grain yield and high quality characteristics were taken to the regional yield trials for further evaluation in the registration phase.

Keywords: Biplot, durum wheat, quality, yield

\section{Giriș}

D urum buğdayın ekmekliğe göre daha özel iklim ve toprak isteklerinin olması dünyanın her yerinde yetiștirilmesini engellemektedir. Yüksek verimli ekmeklik buğday çeșitlerinin yanı sıra, sulu alanların artması sonucu farklı ürünlerin makarnalık buğday ekim alanlarında ekilmesi nedeniyle makarnalık buğday üretiminde önemli oranda düșüșler söz konusu olmaktadır. Azalan makarnalık buğday üretiminin arttırıması için yüksek verimli yeni çeșitlerin ortaya konması büyük önem tașımaktadır. Ayrıca, günümüzde durum buğday üretiminin arttırılması için; yüksek verim yanında makarnalık kalitesi geliștirilmiș çeșitlere yönelik olarak yapılacak ıslah çalıșmalarına ağırlık verilmesi de büyük önem tașımaktadır. Böylece, giderek azalan makarnalık buğday üretimimiz tekrar artacak ve bu ürünü ișleyen tarımsal sanayinin dıșa bağımlılığı azalacaktır (Sözen ve Yağdı 2005). 
Bu çalıșma, GAP UTAEM tarafından geliștirilen ileri kademe durum buğday hatlarının verim ve bazı önemli kalite özelliklerinin saptanması ve üstün özelliklere sahip hatların ilerleyen süreçte çeșit adayı olarak tescile sunulması amacıyla gerçekleștirilmiștir.

\section{Materyal ve Yöntem}

\section{Deneme yeri ve deneme materyali}

$\mathrm{Bu}$ çalıșma, 2012-2013 ve 2013-2014 yetiștirme sezonlarında Diyarbakır GAP UTAEM deneme alanında yürütülmüștür. Çalıșmada 20 hat ile beș standart makarnalık buğday çeșidi (5: Artuklu, 10: Eyyubi, 15: Güneyyıldızı, 20: Șahinbey ve 25: Zühre) materyal olarak kullanılmıștır.

\section{Deneme yeri iklim ve toprak özellikleri}

Denemenin yürütüldüğü 2012-2013 ve 2013-2014 yılları buğday yetiștirme dönemi ile uzun yıllara ait iklim verileri de Çizelge 1'de verilmiștir. Çizelge 1'de görüldüğg̈ gibi, uzun yıllar yıllık sıcaklık değerleri ortalaması $12,8{ }^{\circ} \mathrm{C}$ olarak kaydedilirken, araștırmanın yürütüldüğü 2012-13 ve 2013-14 yetiștirme sezonlarında sırasıyla $14.0{ }^{\circ} \mathrm{C}$ ve $13.0{ }^{\circ} \mathrm{C}$ olarak kaydedilmiștir. Ayrıca Diyarbakır iline ait uzun yıllar toplam yağıș miktarı $484.0 \mathrm{~mm}$ iken, çalıșmanın yürütüldüğü 2012-13 ve 2013-14 yetiștirme sezonlarında $680.6 \mathrm{~mm}$ ve $356.7 \mathrm{~mm}$ șeklinde kaydedilmiștir. 20132014 sezonu, hem düșük yağıșı, hem de kıș döneminde sıfırın altında ve Mart ayı sonunda yașanan don hadisesi ile ekstrem bir sezon olmuștur. Denemenin yürütüldüğü alandan 30 $\mathrm{cm}$ derinliğinden alınan toprak örnekleriyle,
GAP Uluslararası Tarımsal Araștırma ve Eğitim Merkez laboratuarında gerçekleștirilen analiz sonucuna göre; deneme yeri toprağının killi-tınlı bünyede olduğu ve organik madde oranının ise $\% 0.45$ olduğu tespit edilmiștir. Ayrıca toplam tuz \%0.08, PH 7.95, kireç \%13.13, yarayıșlı fosfor $\left(\mathrm{P}_{2} \mathrm{O}_{5}\right) 2.36 \mathrm{~kg} \mathrm{da}^{-1}$ olarak saptanmıștır.

\section{Yöntem}

Deneme, tesadüf blokları bölünmüș parseller deneme desenine göre üç tekerrürlü olarak yürütülmüștür. Ekimler, altı sıralı parsel mibzeri ile 500 adet $\mathrm{m}^{2}$ tohum normunda yapılmıștır. Parseller, ekimde $7.2 \mathrm{~m}^{2}$ (6 sıra $\mathrm{x}$ $20 \mathrm{~cm}$ sıra arası $\times 6 \mathrm{~m}$ uzunluk), hasatta ise $6 \mathrm{~m}^{2}(6$ sırax $20 \mathrm{cmsıraarası} 5$ muzunluk)șeklinde olușturulmuștur. Denemelerde ekimle birlikte taban gübresi olarak dekara saf madde olarak 8 $\mathrm{kg} \mathrm{N}+8 \mathrm{~kg} \mathrm{P}_{2} \mathrm{O}_{5}$, kardeșlenme döneminde ise $6 \mathrm{~kg} \mathrm{~N}$ üst gübre olarak kullanılmıștır. Denemelerde yabancı ot kontrolü için bir kez ilaçlama yapılmıș olup, hasat ișlemi ise parsel biçerdöveri ile yapılmıștır. Araștırmada tane verimi, bin tane ve hektolitre ağırlığı, protein içeriği, tane rengi ve SDS değeri üzerinden incelemeler yapılmıștır.

\section{Incelenen özellikler ve veri analizi}

Tane verimi, bin tane ağırlığı, hektolitre ağırlı̆̆ı, protein içeriği, tane rengi ve SDS değeri üzerinden incelemeler yapılmıștır. Elde edilen verilerin JMP 5.0.1 paket programı ile varyans analizi yapılmıș, ortalamalar arası farklıık, LSD (\%5) çoklu karșılaștırma testine göre tespit edilmiștir. Çalıșmada özellikler arası ilișkileri görsel olarak inceleme ve değerlendirmek

Çizelge 1. Diyarbakır'ın sıcaklık değerleri ve yağıș miktarı Table 1. Temperature values and precipitation amount of Diyarbakir

\begin{tabular}{ccccccc}
\hline \multirow{2}{*}{ Aylar } & \multicolumn{3}{c}{ Ortalama sıcaklık $\left({ }^{\circ} \mathrm{C}\right)$} & \multicolumn{3}{c}{ Yağıș $(\mathrm{mm})$} \\
\cline { 2 - 7 } & $2012-2013$ & $2013-2014$ & Uzun Yıllar & $2012-2013$ & $2013-2014$ & Uzun Yıllar \\
\hline Eylül & 26.1 & 24.4 & 24.8 & 1.8 & 0.0 & 4.1 \\
Ekim & 18.5 & 16.9 & 17.2 & 107.4 & 0.0 & 34.7 \\
Kasım & 12.0 & 11.3 & 9.2 & 83.2 & 54.0 & 51.8 \\
Aralık & 5.1 & -3.4 & 4.0 & 160.8 & 50.4 & 71.4 \\
Ocak & 2.7 & 3.4 & 1.8 & 82.2 & 43.0 & 68.0 \\
Șubat & 6.1 & 6.0 & 3.5 & 85.2 & 38.6 & 68.8 \\
Mart & 9.5 & 10.8 & 8.5 & 19.8 & 60.6 & 67.3 \\
Nisan & 14.5 & 14.7 & 13.8 & 39.4 & 39.9 & 68.7 \\
Mayıs & 19.0 & 19.8 & 19.3 & 98.0 & 48.8 & 41.3 \\
Haziran & 26.8 & 26.6 & 26.3 & 2.8 & 21.4 & 7.9 \\
Toplam & 14.0 & 13.0 & 12.8 & 680.6 & 356.7 & 484.0 \\
\hline
\end{tabular}


amacıyla genotip verileri ile olușturulan GGE Biplot analizleri, Yan (2001) ile Yan and Kang (2003)'ın belirttikleri yöntemler esas alınarak gerçekleștirilmiș, grafiklerdeki önemlilik dereceleri ise vektör grafiklerindeki vektörler arası açılar dikkate alınarak belirlenmiștir (Yan, 2002; Sayar ve Han, 2015). Çalıșma, GGE Biplot analiz grafikleri Genstat $14^{\text {th }}$ paket programı kullanılarak yapılmıștır.

\section{Bulgular ve Tartıșma}

Çalıșmada incelenen tüm özelliklere ait ortalama değerler ve önemlilik grupları Çizelge 2 ve Çizelge 3'te verilmiștir. Yapılan bileșik analizde; genotip, yll ve genotip $x$ yıl interaksiyonunda $\% 1$ düzeyinde önemli farklılıklar tespit edilmiștir.

\section{Tane Verimi (kg da-1)}

Araștırmada incelenen tane verimi açısından tüm varyasyon kaynakları $\% 1$ düzeyinde önemli bulunmuștur (Çizelge 2). En yüksek tane verimi $483.9 \mathrm{~kg} \mathrm{da}^{-1}$ ile Eyyubi çeșidinden elde edilirken, en düșük tane verimi $347.4 \mathrm{~kg}$ $\mathrm{da}^{-1}$ ile 16 nolu hattan elde edilmiștir. Birinci yılda, uzun yılların çok üzerinde gerçekleșen yağıș sebebiyle tane verimi yüksek olmuștur. İkinci yıl ise hem yağıș miktarının düșük olması hem de yașanan kıș soğukları ile ilkbahar geç donları sebebiyle tane veriminde ciddi bir düșüș gözlenmiștir. Tane verimine ait genotip $x$ yıl interaksiyonunun önemli olması, düșük/ orta kalıtım derecesi ve çevreden etkilenmeyle izah edilebilir.

Çizelge 2. Tane verimi, bin tane ve hektolitre ağırlığına ilișkin ortalama değerler ve olușan gruplar Table 2. Mean values related with grain yield, thousand kernel weight and hectoliter weight and groups

\begin{tabular}{|c|c|c|c|c|c|c|c|c|c|}
\hline \multirow{3}{*}{ Genotip } & \multicolumn{3}{|c|}{ Tane Verimi $\left(\mathrm{kg} \mathrm{da}^{-1}\right)$} & \multicolumn{3}{|c|}{ Bin Tane Ağırlığı (g) } & \multicolumn{3}{|c|}{ Hektolitre Ağırlığı $\left(\mathrm{kg} \mathrm{h}^{-1}\right)$} \\
\hline & \multicolumn{2}{|c|}{ Genotip x Yıl İnt. } & \multirow{2}{*}{ Ortalama } & \multicolumn{2}{|c|}{ Genotip x Yıl İnt. } & \multirow{2}{*}{ Ortalama } & \multicolumn{2}{|c|}{ Genotip x Yıl İnt. } & \multirow{2}{*}{ Ortalama } \\
\hline & $2012-2013$ & 2013-2014 & & $2012-2013$ & 2013-2014 & & $2012-2013$ & 2013-2014 & \\
\hline 1 & 624.3 & 242.4 & 433.4 & 39.1 & 23.9 & 31.5 & 86.3 & 80.1 & 83.2 \\
\hline 2 & 486.6 & 222.9 & 354.8 & 50.0 & 28.4 & 39.2 & 85.5 & 80.4 & 82.9 \\
\hline 3 & 454.6 & 264.8 & 359.7 & 42.8 & 29.0 & 35.9 & 86.8 & 82.7 & 84.8 \\
\hline 4 & 586.7 & 329.8 & 458.3 & 41.3 & 27.9 & 34.6 & 84.0 & 77.9 & 81.0 \\
\hline 5 & 536.0 & 339.8 & 437.9 & 45.8 & 34.0 & 39.9 & 86.6 & 83.0 & 84.8 \\
\hline 6 & 465.0 & 235.0 & 350.0 & 37.3 & 26.3 & 31.8 & 85.2 & 81.3 & 83.2 \\
\hline 7 & 609.4 & 240.3 & 424.8 & 42.5 & 25.4 & 33.9 & 86.8 & 80.9 & 83.8 \\
\hline 8 & 546.3 & 229.3 & 387.8 & 40.6 & 23.8 & 32.2 & 84.0 & 78.7 & 81.3 \\
\hline 9 & 614.7 & 236.6 & 425.6 & 41.0 & 24.1 & 32.6 & 86.2 & 78.9 & 82.5 \\
\hline 10 & 651.0 & 316.8 & 483.9 & 46.1 & 31.1 & 38.6 & 87.5 & 84.1 & 85.8 \\
\hline 11 & 545.8 & 237.8 & 391.8 & 40.9 & 26.4 & 33.6 & 84.9 & 79.0 & 81.9 \\
\hline 12 & 506.9 & 235.6 & 371.3 & 40.8 & 26.3 & 33.5 & 85.7 & 80.7 & 83.2 \\
\hline 13 & 609.1 & 281.9 & 445.5 & 36.6 & 24.4 & 30.5 & 83.4 & 77.9 & 80.6 \\
\hline 14 & 590.1 & 264.4 & 427.3 & 37.5 & 24.4 & 30.9 & 82.6 & 75.6 & 79.1 \\
\hline 15 & 628.3 & 222.3 & 425.3 & 43.0 & 27.6 & 35.3 & 85.8 & 80.3 & 83.0 \\
\hline 16 & 537.8 & 156.9 & 347.4 & 36.0 & 24.5 & 30.3 & 86.6 & 80.6 & 83.6 \\
\hline 17 & 513.8 & 191.5 & 352.6 & 38.0 & 25.4 & 31.7 & 86.0 & 80.7 & 83.4 \\
\hline 18 & 581.4 & 202.9 & 392.2 & 43.5 & 24.5 & 34.0 & 86.4 & 79.9 & 83.1 \\
\hline 19 & 518.3 & 203.2 & 360.8 & 34.6 & 24.3 & 29.4 & 84.9 & 81.0 & 83.0 \\
\hline 20 & 610.3 & 225.3 & 417.8 & 43.0 & 28.4 & 35.7 & 86.2 & 80.4 & 83.3 \\
\hline 21 & 503.9 & 247.1 & 375.5 & 47.6 & 32.5 & 40.1 & 87.8 & 84.8 & 86.3 \\
\hline 22 & 500.4 & 244.0 & 372.2 & 50.4 & 33.1 & 41.8 & 86.5 & 80.8 & 83.6 \\
\hline 23 & 502.1 & 255.5 & 378.8 & 45.9 & 29.0 & 37.4 & 87.3 & 83.3 & 85.3 \\
\hline 24 & 507.3 & 300.8 & 404.0 & 53.9 & 31.0 & 42.4 & 87.5 & 84.2 & 85.8 \\
\hline 25 & 584.2 & 250.4 & 417.3 & 43.4 & 27.3 & 35.3 & 86.6 & 80.5 & 83.6 \\
\hline YII & 552.6 & 247.1 & 399.8 & 42.5 & 27.3 & 34.9 & 85.9 & 80.7 & 83.3 \\
\hline \multirow{3}{*}{ AÖF } & \multirow{2}{*}{\multicolumn{2}{|c|}{ Genotip }} & $63.5^{* *}$ & Genotip & & $1.9^{\text {** }}$ & \multicolumn{2}{|l|}{ Genotip } & $1.1^{\star \star}$ \\
\hline & & & $80.4^{\star *}$ & Yıl & & $1.7^{\star \star}$ & \multirow{2}{*}{\multicolumn{2}{|c|}{$\begin{array}{l}\text { YIl } \\
\text { Genotip x YIl }\end{array}$}} & $1.3^{* *}$ \\
\hline & \multicolumn{2}{|c|}{ Genotip x Yıl } & $89.4^{* \star}$ & Genotip > & SYll & $2.7^{\text {** }}$ & & & $1.6^{\star \star}$ \\
\hline DK (\%) & \multicolumn{3}{|c|}{11.2} & \multicolumn{3}{|c|}{3.9} & \multicolumn{3}{|c|}{1.0} \\
\hline
\end{tabular}




\section{Bin Tane Ağırlığı (g)}

Yapılan bileșik analizde; tüm varyasyon kaynakları arasında \%1 düzeyinde önemli farklılık gözlenmiștir (Çizelge 2). En yüksek bin tane ağırlığı 42.4 gr ile 24 nolu, en düșük bin tane ağırlığı ise 30.3 gr ile 16 nolu hattan elde edilmiștir. Birinci yıl, gerçekleșen çok yüksek yağıș sebebiyle daha yüksek bin tane ağırlığı elde edilmiștir. Çalıșmamızla paralel olarak, Kılıç (2003)'ın aynı bölgede yaptığı çalıșmada genotipin çevresel faktörlere göre bin tane ağırlığı üzerinde daha etkili olduğunu bildirmekle beraber, interaksiyonların da bin tane ağırlığı üzerinde etkili olduğunu vurgulamaktadır.

\section{Hektolitre Ağırlığı (kg hl-1)}

Yapılan bileșik analizde; tüm varyasyon kaynakları arasında \%1 düzeyinde önemli farklılık gözlenmiștir (Çizelge 2). En yüksek hektolitre ağırlığı $86.3 \mathrm{~kg} \mathrm{hl}^{-1}$ ile 21 nolu hattan, en düșük hektolitre ağırlığı ise $79.1 \mathrm{~kg} \mathrm{hl}^{-1}$ ile 14 nolu hattan elde edilmiștir. Birinci yıl, gerçekleșen çok yüksek yağıș sebebiyle daha yüksek hektolitre ağırlığına sahip olmuștur. Aydın ve ark. (1993), bu özelliğin genotip ve çevreden etkilendiğini; Kılıç (2003) da, hektolitre ağırlığı üzerinde genotip $x$ çevre interaksiyonlarının etkili ve önemli olduğunu bildirmektedirler. Nitekim çalıșmamızda da genotip x yıl interaksiyonu önemli çıkmıștır.

\section{Protein İçeriği (\%)}

Yapılan bileșik analizde tüm varyasyon kaynakları arasında \%1 düzeyinde önemli farklılık gözlenmiștir (Çizelge 3). En yüksek protein içeriği \%16.7 ile Güneyyıldızı çeșidinden, en düșük protein içeriği ise \%14.0 ile 4 nolu hattan elde edilmiștir. İlk yıl protein

Çizelge 3. Protein içeriği, tane rengi ve SDS değerine ilișkin ortalama değerler ve olușan gruplar Table 3. Mean values related with protein content, kernel colour and SDS value and groups

\begin{tabular}{|c|c|c|c|c|c|c|c|c|c|}
\hline \multirow{3}{*}{ Genotip } & \multicolumn{3}{|c|}{ Protein İçeriği (\%) } & \multicolumn{3}{|c|}{ İrmik Rengi (b değeri) } & \multicolumn{3}{|c|}{ SDS (ml) } \\
\hline & \multicolumn{2}{|c|}{ Genotip x Yıl İnt. } & \multirow{2}{*}{ Ortalama } & \multicolumn{2}{|c|}{ Genotip x Yıl İnt. } & \multirow{2}{*}{ Ortalama } & \multicolumn{2}{|c|}{ Genotip x Yıl İnt. } & \multirow{2}{*}{ Ortalama } \\
\hline & $2012-2013$ & 2013-2014 & & $2012-2013$ & 2013-2014 & & $2012-2013$ & $2013-2014$ & \\
\hline 1 & 11.6 & 19.2 & 15.4 & 25.2 & 26.4 & 25.8 & 22.5 & 30.0 & 26.3 \\
\hline 2 & 12.9 & 19.0 & 16.0 & 23.8 & 25.6 & 24.7 & 15.0 & 28.5 & 21.8 \\
\hline 3 & 12.2 & 18.9 & 15.5 & 22.1 & 23.6 & 22.9 & 16.5 & 25.0 & 20.8 \\
\hline 4 & 10.9 & 17.1 & 14.0 & 22.7 & 24.0 & 23.3 & 17.0 & 25.0 & 21.0 \\
\hline 5 & 11.3 & 17.5 & 14.4 & 20.2 & 22.3 & 21.2 & 12.5 & 18.0 & 15.3 \\
\hline 6 & 11.5 & 18.8 & 15.2 & 22.1 & 23.1 & 22.6 & 16.0 & 21.0 & 18.5 \\
\hline 7 & 11.9 & 19.1 & 15.5 & 21.5 & 23.7 & 22.6 & 15.5 & 24.5 & 20.0 \\
\hline 8 & 11.9 & 19.6 & 15.7 & 23.4 & 25.0 & 24.2 & 19.5 & 25.5 & 22.5 \\
\hline 9 & 10.9 & 18.7 & 14.8 & 22.5 & 25.0 & 23.7 & 14.5 & 29.0 & 21.8 \\
\hline 10 & 12.3 & 18.7 & 15.5 & 20.8 & 22.0 & 21.4 & 18.0 & 26.0 & 22.0 \\
\hline 11 & 12.7 & 19.0 & 15.8 & 23.6 & 24.5 & 24.0 & 21.0 & 25.0 & 23.0 \\
\hline 12 & 11.8 & 19.2 & 15.5 & 23.2 & 22.7 & 23.0 & 18.0 & 21.5 & 19.8 \\
\hline 13 & 11.8 & 18.6 & 15.2 & 25.1 & 26.0 & 25.6 & 23.0 & 29.0 & 26.0 \\
\hline 14 & 11.3 & 19.0 & 15.1 & 27.9 & 30.0 & 28.9 & 15.5 & 27.0 & 21.3 \\
\hline 15 & 13.5 & 19.9 & 16.7 & 24.2 & 24.8 & 24.5 & 16.5 & 20.5 & 18.5 \\
\hline 16 & 12.4 & 19.3 & 15.8 & 24.4 & 24.0 & 24.2 & 17.0 & 25.0 & 21.0 \\
\hline 17 & 12.3 & 20.4 & 16.3 & 22.5 & 25.4 & 23.9 & 13.5 & 18.0 & 15.8 \\
\hline 18 & 11.8 & 19.4 & 15.6 & 21.5 & 23.8 & 22.7 & 15.5 & 23.0 & 19.3 \\
\hline 19 & 12.5 & 18.9 & 15.7 & 23.4 & 24.7 & 24.0 & 13.5 & 14.0 & 13.8 \\
\hline 20 & 12.0 & 21.2 & 16.6 & 23.0 & 23.9 & 23.4 & 13.0 & 20.5 & 16.8 \\
\hline 21 & 12.3 & 19.0 & 15.7 & 19.3 & 19.6 & 19.4 & 14.5 & 21.5 & 18.0 \\
\hline 22 & 14.1 & 18.8 & 16.5 & 21.8 & 22.6 & 22.2 & 20.0 & 17.5 & 18.8 \\
\hline 23 & 12.4 & 18.1 & 15.3 & 22.3 & 21.6 & 21.9 & 18.5 & 24.0 & 21.3 \\
\hline 24 & 13.3 & 17.3 & 15.3 & 19.2 & 21.2 & 20.2 & 14.5 & 19.5 & 17.0 \\
\hline 25 & 12.4 & 20.5 & 16.4 & 22.2 & 23.9 & 23.0 & 16.5 & 24.5 & 20.5 \\
\hline YII & 12.2 & 19.0 & 15.6 & 22.7 & 24.0 & 23.3 & 16.7 & 23.3 & 20.0 \\
\hline \multirow{3}{*}{ AÖF } & \multicolumn{2}{|l|}{ Genotip } & 0.9 ** & Genotip & & 1.9 ** & \multicolumn{2}{|l|}{ Genotip } & $1.1^{\star \star}$ \\
\hline & \multirow{2}{*}{\multicolumn{2}{|c|}{$\begin{array}{l}\text { YIl } \\
\text { Genotip x YIl }\end{array}$}} & $0.6^{* \star}$ & YII & & $1.7^{\star \star}$ & \multirow{2}{*}{\multicolumn{2}{|c|}{$\begin{array}{l}\text { YIl } \\
\text { Genotip x YIl }\end{array}$}} & $1.3^{\star \star}$ \\
\hline & & & $1.3^{* *}$ & Genotip & $x Y_{I I}$ & $2.7^{\star \star}$ & & & $1.6^{* \star}$ \\
\hline DK (\%) & \multicolumn{3}{|c|}{4.2} & \multicolumn{3}{|c|}{2.5} & \multicolumn{3}{|c|}{8.1} \\
\hline
\end{tabular}




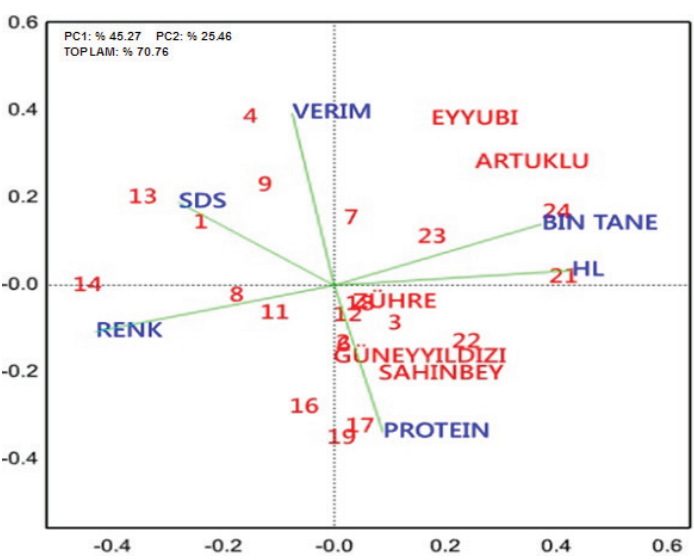

Șekil 1. Genotip x özellik ilișkisini gösteren Biplot grafiği.

Figure 1. Biplot graph showing relation of genotype $x$ feature.

içeriği ikinci yıla göre daha düșük olmuștur. Bu durum birinci yıl gerçekleșen yüksek yağıșlarla ilișkilidir. Yüksek yağıșla birlikte gerçekleșen daha uzun sarı olum döneminde nișasta birikiminde artıșlar meydana gelmekte ve bu da protein bantlarının parçalanarak protein içeriğinin azalmasına yol açmaktadır. Nitekim, Nachit et al. (1993) hem sulanır hem de yağıșlı șartlarda protein oranının çevreden daha çok etkilendiğini bildirmektedirler.

\section{Irmik Rengi (b değeri)}

Yapılan bileșik analizde tüm varyasyon kaynakları arasında \%1 düzeyinde önemli farklılık gözlenmiștir (Çizelge 3). En yüksek b değeri 28.9 ile 14 nolu hattan elde edilirken, en düșük b değeri 19.4 ile 21 nolu hattan elde edilmiștir. İkinci yıl b değerinin daha yüksek olması, farklı çevre șartları ile izah edilebilir. Nitekim Taghouti et al. (2010), renk değerinin genotipik bir özellik olsa da çevreden de biraz etkilendiğini bildirmektedirler.

\section{SDS değeri (ml)}

Yapılan bileșik analizde tüm varyasyon kaynakları arasında \%1 düzeyinde önemli farklılık gözlenmiștir (Çizelge 3). En yüksek SDS değeri $26.3 \mathrm{ml}$ ile 1 nolu hattan, en düșük SDS değeri ise $13.8 \mathrm{ml}$ ile 19 nolu hattan elde edilmiștir. Protein içeriği ile ilișkili olan bu özelliğin de ikinci yıl ortalaması daha yüksek

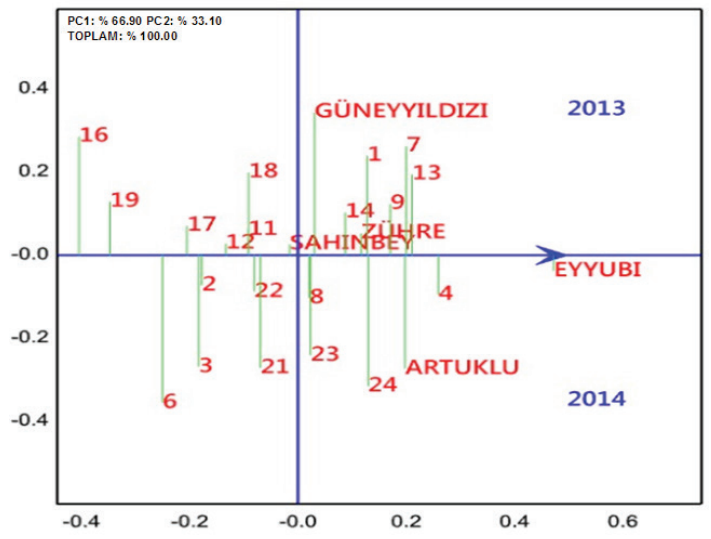

Șekil 2. Genotip x yıl ilișkisini gösteren Biplot grafiği.

Figure 2. Biplot graph showing relation of genotype $x$ year.

olmuștur. Bunun da birinci yıl gerçekleșen yüksek yağıștan kaynaklandığı düșünülebilir. Yapılan bazı çalıșmalarda da, benzer șekilde sedim değerinin genotip $\mathrm{x}$ çevre interaksiyonundan etkilendiği bildirilmiștir (Kılıç 2003).

\section{GGE Biplot Grafikleri ile Genotip ve Özelliklerin Değerlendirilmesi}

Genotip ve özellikler arası ilișkileri görsel olarak inceleme ve değerlendirme imkanı sunan Biplot grafikleri Șekil 1 ve 2'de verilmiștir. Șekil 1'de görüldüğü gibi, değerlendirilen özellikler açısından hangi genotiplerin öne çıktığı, hangilerinin birbiri ile olumlu veya olumsuz ilișkide olduğu grafikte gözlenmektedir. Șekil 2'de ise hangi genotiplerin hangi yılda öne çıktıkları görülmektedir. Ayrıca genotiplerin stabilite çizgisine olan mesafeleri de gözlenmekte olup, Eyyubi çeșidinin stabilite çizgisine en yakın genotip olduğu görülmektedir. Çalıșma sonucunda, verim ve kalite özellikleri yönünden ümitvar görünen hatlar, bölge verim denemelerine aktarılmıștır.

\section{Teșekkür}

$\mathrm{Bu}$ çalıșmanın yürütülmesinde TAGEM/ TA/11/07/02/003 nolu proje ile destek olan Tarımsal Araștırmalar ve Politikalar Genel Müdürlügüne teșekkür ederiz. 


\section{Kaynaklar}

Aydın F., Koçak N. ve Dağ A., 1993. Bazı buğday çeșitlerinin bulgur kalitesinin belirlenmesi üzerine bir araștırma. Makarnalık Buğday ve Mamülleri Sempozyumu, 30 Kasım-3 Aralık, Ankara, s. 310-317

Kılıç H., 2003. Güneydoğu Anadolu Bölgesi koșullarında makarnalık buğday (Triticum turgidum ssp. durum) çeșitlerinin bazı tarımsal ve kalite özellikleri ile stabilitesi üzerine araștırmalar. Doktora tezi, Çukurova Üniversitesi Fen Bilimleri Enstitüsü, Adana

Nachit M.M., Baum M., Impiglia A., Ketata H., 1993. Studies on some grain quality traits in durum wheat grown in Mediterranean environments. Proceedings International Symposium on Durum Wheat Quality in the Mediterranean Region, Zaragoza, Spain, 181-187

Sayar M.S. ve Han Y., 2015. Determination of seed yield and yield components of grasspea (Lathyrus sativus L.) lines and evaluations using GGE Biplot analysis method. Tarım Bilimleri Dergisi - J. Agric. Sci., 21(1): 78-92
Sözen E. ve Yağdı K., 2005. Bazı İleri Makarnalık Buğday Hatlarının Kalite Özelliklerinin Belirlenmesi. Uludağ Üniversitesi Ziraat Fakültesi Dergisi. 19 (2): 69-81

Taghouti M., Gaboun F., Nsarellah N., Rhrib R., El-Haila M., Kamar M., Abbad-Andaloussi F., Udupa S.M., 2010. Genotype x environment interaction for quality traits in durum wheat cultivars adapted to different environments. African Journal of Biotechnology Vol. 9(21), pp. 3054-3062

Yan W., 2001. GGE biplot: a windows application for graphical analysis of multi-environment trial data and other types of two way data. Agron J 93:1111-1118

Yan W., 2002. Singular-value partitioning for biplot analysis of multienvironment trial data. Agron $\mathrm{J}$ 94: 990-996. doi:10.2134/agronj2002.9900

Yan W., Kang M.S., 2002. GGE Biplot Analysis: A graphical tool for breeders, geneticists, and agronomists. CRC Press, Boca Raton, FL, pp.288 